\title{
Influence of temperature during the second fermentation and aging of sparkling wine (Cava) on the properties of the foam
}

\author{
Mireia Esteruelas ${ }^{1}$, Elena González-Royo ${ }^{1}$, Mariona Gil ${ }^{1}$, Nikolaos Kountoudakis ${ }^{1}$, Antonio Orte ${ }^{2}$, Antonio Cantos $^{2}$, \\ Francesca Fort ${ }^{1}$, Joan Miquel Canals ${ }^{1}$, and Fernando Zamora ${ }^{1, a}$
${ }^{1}$ Departament de Bioquímica i Biotecnologia, Facultat d'Enologia de Tarragona, Universitat Rovira i Virgili, Campus de Sescelades, C/Marcel.li Domingo, s/n., 43007 Tarragona, Spain
${ }^{2}$ Juvé \& Camps SA, c/Sant Venat, 1, 08770 Sant Sadurní d'Anoia, Barcelona, Spain

\begin{abstract}
The aim of this study was to determine the influence of temperature during the second fermentation and aging of sparkling wines (AOC Cava) on their foam properties. The results indicate that sparkling wines elaborated at $12^{\circ} \mathrm{C}$ have a maximum height (HM) and a stable height (HS) of the foam significantly higher than the corresponding ones produced at $16^{\circ} \mathrm{C}$. This better foam properties observed in sparkling wines obtained at low temperature are probably related with their higher protein and oligosaccharide concentration.
\end{abstract}

\section{Introduction}

Foam stability is, without any doubt, one of the most important qualitative aspects to consider in the production of sparkling wines, and consequently one of the best sensory attributes considered by manufacturers and consumers $[1,2]$. It is for this reason that the knowledge of the factors that influence the foamability and the foam persistence is a topic of great interest for the wine science $[3,4]$.

The existing literature on the subject is abundant but the current knowledge still has not completely solved this issue. Some studies have shown that the foaming properties of sparkling wines are closely related to their chemical composition [3-5] which, in turn, depends on such factors as varietal origin, grape maturity and winemaking conditions [6-9]. In this regard it seems that foam stability is significantly favored by the presence of surface active agents which can stabilize foam by settling at the bubble's film, their hydrophobic head turned towards the gas, and their hydrophilic tail turned towards the aqueous phase $[10,11]$. Of the various foam active substances, proteins, mannoproteins and polysaccharides seem to play a major role because of their surface properties $[3,12,13]$.

It has been also published many papers about the influence of winemaking and stabilization of the base wine $[8,14]$, the yeast strain used in the first and second fermentation $[15,16]$, autolysis $[17,18]$, the influence of riddling adjuvants [14], etc. However, to our knowledge there is not any study about the influence of temperature during the second fermentation and aging time on sparkling wines. For that reason the aim of this work was to study how the temperature during second fermentation and aging affects sparkling wine composition a foam parameters.

${ }^{a}$ Corresponding author: fernando.zamora@urv.cat

\section{Materials and methods}

The experiment was carried in the winery Juve \& Camps in Sant Sadurní d'Anoia (AOC Cava, Spain). A base wine corresponding to an coupage of Xarel.lo, Macabeo and Parellada (50/35/15) cultivars was added with $23 \mathrm{~g} / \mathrm{l}$ of sugar (rectified concentrated must), $2 \mathrm{~g} / \mathrm{hl}$ of a riddling adjuvant based on bentonite and alginates (adjuvant MO; Station Oenotechnique of Champagne), and a population of 1 million of viable cells/ml of the Saccharomyces cerevisiae yeast (18-2007 IOC; Oenologique Institut de Champagne) previously adapted for secondary fermentation. After that the wine was bottled for the production of sparkling wine (Cava) using the traditional method. A batch of bottles was kept at $16 \pm 1^{\circ} \mathrm{C}$ and the other at $12 \pm 1^{\circ} \mathrm{C}$ for 14 months. After this time, the bottles were removed, decapitated and used for the analysis of the foaming properties (MOSALUX) [19], proteins (HRSECDAD) [20] and polysaccharides (HRSEC-RID) [21]. All analyses were performed in triplicate using three different bottles for it.

\section{Results and discussion}

Figure 1 shows the foam parameters of the sparkling wines obtained at different temperatures. The results are very clear and show that sparkling wines elaborated at $12^{\circ} \mathrm{C}$ had a maximum height (HM) and a stable height (HS) of the foam significantly higher than the corresponding ones produced at $16^{\circ} \mathrm{C}$.

This data indicates that the sparkling wines produced at low temperature exhibit better foamability and more persistent foam.

Figure 2 shows the results of protein analysis by HRSEC-DAD. In all the wines studied, three protein fractions were obtained. The high molecular weight fraction 


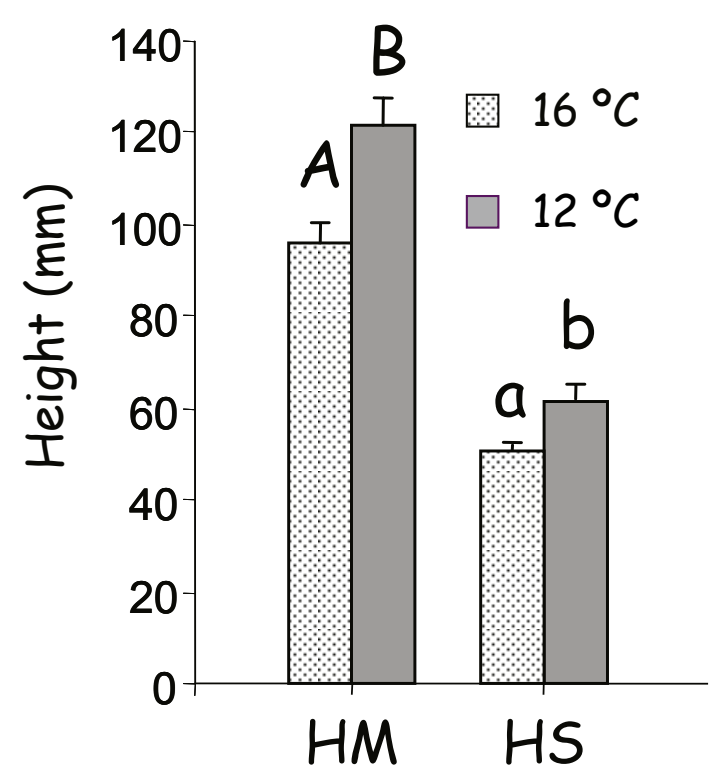

Figure 1. Influence of temperature on foam parameters. Different letters indicate significant statistical differences $(p<0.05)$.

(PR1) has a molecular weight higher than $80 \mathrm{kDa}$, the intermediate molecular weight fraction (PR2) has a molecular weight around $60 \mathrm{kDa}$ and the low molecular weight fraction (PR3) has a molecular weight below $40 \mathrm{kDa}$.

These results indicate that total protein (PRT) of sparkling wines obtained at $12^{\circ} \mathrm{C}$ is significant higher than in those obtained at $16^{\circ} \mathrm{C}$, and that these increase was mainly due to the low molecular weight fraction (PR3).

Figure 3 shows the results of polysaccharide analysis by HRSEC-RID. In all the wines studied, three fractions of polysaccharides and two fractions of oligosaccharides were obtained. The high molecular weight fraction (PO1) has a molecular weight higher than $180 \mathrm{kDa}$, the intermediate molecular weight fraction (PO2) has a molecular

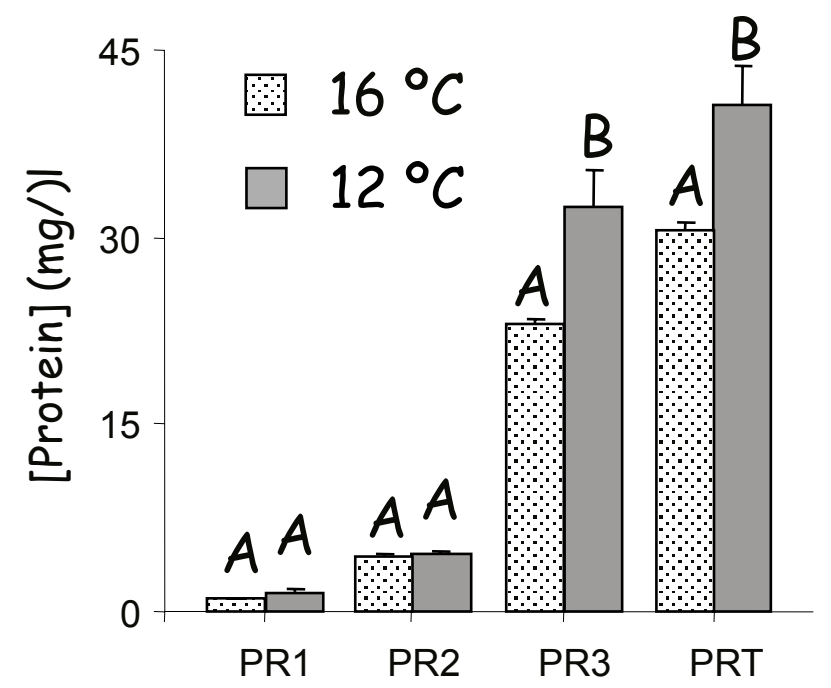

Figure 2. Influence of temperature on protein fraction of sparkling wines. Different letters indicate significant statistical differences $(p<0.05)$.

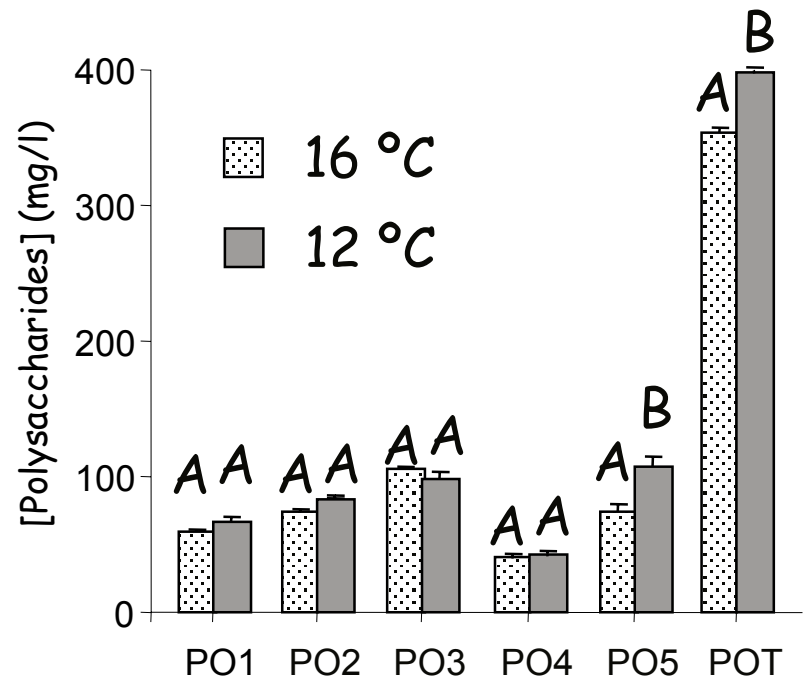

Figure 3. Influence of temperature on polysaccharide and oligosaccharide fractions of sparkling wines. Different letters indicate significant statistical differences $(p<0.05)$.

weight between 180 and $40 \mathrm{kDa}$ and the low molecular weight fraction (PO3) has a molecular weight between 40 and $7.5 \mathrm{kDa}$. Oligosaccharide fractions (PO4 and PO5) have a molecular weight lower than $7.5 \mathrm{kDa}$.

The results indicate that sparkling wines obtained at $12^{\circ} \mathrm{C}$ have similar total polysaccharide concentration significant higher that those obtained at $16^{\circ} \mathrm{C}$. However, this increase was only due to the oligosaccharide fraction of lowest molecular weight (PO5) being the other fractions very similar between both temperatures.

Proteins and mannoproteins have been described as positive factors for foam $[3,12,13]$. Consequently, the higher protein and oligosaccharide concentrations detected in sparkling wines obtained at $12^{\circ} \mathrm{C}$ may be probably the reason because the maximum height (HM) and a stable height (HS) were significant better.

\section{Conclusion}

It can be concluded that temperature of the second fermentation and aging has a significant influence on the composition and foam quality of sparkling wine. Consequently, the correct temperature control of the cellars, in which the second fermentation and aging of sparkling wines bottles, is a key point to guarantee its foam quality.

\section{References}

[1] G. Liger-Belair, Uncorked: The Science of Champagne (Revised Edition). Princenton, New Jersey. Princenton University (2004)

[2] M. Esteruelas, E. González-Royo, N. Kontoudakis, A. Orte, A. Cantos, J.M. Canals, F. Zamora, (2014) J. Sci. Food Agric. In press. DOI: 10.1002/jsfa.6922

[3] F. Brissonet, A. Maujean, Am. J. Enol. Vitic. 42, 97-102 (1991)

[4] E. Pueyo P.J. Martín-Alvarez, M.C. Polo, Am. J. Enol. Vitic. 46, 518-524 (1995) 
[5] G. Vanrell, P. Cabanillas, S. Albet, J.M. Canals, L. Arola, F. Zamora, Rev. Franç. Oenol. 196, 30-36 (2002)

[6] B. Robillard, E. Delpuech, I. Viaux, J. Malvy, M. Vignes-Adler, B. Duteurtre, Am. J. Enol. Vitic. 44, 387-92 (1993)

[7] R. Marchal, D. Chaboche, R. Douillard, P. Jeandet, J. Agric. Food Chem. 50, 1420-1428 (2002)

[8] G. Vanrell, M. Esteruelas, J.M. Canals, F. Zamora, Rev. Enol. 114, 28-30 (2005)

[9] C. Cilindre, G. Liger-Belair, S. Villaume, P. Jeandet, R. Marchal, Anal. Chim. Acta 660, 164-170 (2010)

[10] C.W. Bamforth, J. I. Brewing, 91, 370-83 (1985)

[11] Schramm LL, Emulsions, Foams and Suspensions; Fundamentals and Applications. WILEY-VCH Verlag GmbH \& Co. KGaA, Weinheim (2005)

[12] F. Brissonnet, A. Maujean, Am. J. Enol. Vitic. 44, 297-301 (1993)

[13] V. Aguié-Béghin, Y. Adriaensen, N. Péron, M. Valade, P. Rouxhet, R. Douillard, J. Agric. Food Chem. 57, 10399-10407 (2009)
[14] G. Vanrell, R. Canals, M. Esteruelas, F. Fort, J.M. Canals, F. Zamora, Food Chem. 104, 148-155 (2007)

[15] J. Torrens, P. Urpí, M. Riu-Aumatell, S. Vichi, E. López-Tamames, S. Buxaderas, Int. J. Food Microb, 124, 48-57 (2008)

[16] E. González-Royo, O. Pascual, N. Kontoudakis, M. Esteruelas, B. Esteve-Zarzoso, A. Mas, J.M. Canals, F. Zamora, Eur. Food Res. Technol, 240, 999-1012 (2015)

[17] B.E.N. Todd, G.H. Fleet, P.A. Henschke, Am. J. Enol. Vitic. 51, 65-72 (2000)

[18] Y.P. Nuñez, A.V. Carrascosa, R. González, M.C. Polo, A.J. Martínez-Rodriguez, J. Agric. Food Chem. 53, 7232-7237 (2005).

[19] A. Maujean, P. Poinsaut, H. Dantan, F. Brissonet, E. Cossiez, Bulletin de l'OIV, 711-712, 405-426 (1990)

[20] J.M. Canals, L. Arola, F. Zamora, Am. J. Enol. Vitic. 49, 383-388 (1998)

[21] B. Ayestaran, Z. Guadalupe, D. Leon, Anal. Chim. Acta 513, 29-39 (2004) 